\title{
Topping and Manual Pruning Effects on the Production of Commercially Valuable Fruit in a Midseason Navel Orange Variety
}

\author{
Craig E. Kallsen
}

AdDitional Index words. Citrus sinensis, crop production, fruit quality, fruit size, 'Frost nucellar', San Joaquin Valley

SumMary. The objective of this experiment was to determine how yield, size, and quality of fruit would respond to mechanical topping and manual pruning of mature 'Frost nucellar' navel orange (Citrus sinensis) trees. Mechanically topping trees at $4.3 \mathrm{~m}(14 \mathrm{ft})$ or $4.9 \mathrm{~m}$ (16 $\mathrm{ft}$ ) produced annual fruit yields and quality similar to that of untopped trees. Over the 4 years of this experiment, trees that were not manually pruned produced as much or more of the most valuable fruit sizes than either the severe or moderate manual pruning treatments without the associated pruning costs. Manual pruning did not improve fruit grade compared to unpruned trees. A highly significant positive and linear relationship was found between numbers of commercially valuable fruit and the total number of fruit produced annually within the range of 50,000 to 325,000 fruit/ha $(20,235$ to 131,528 fruit/acre). Manual pruning, which reduced total fruit numbers, reduced the number of commercially valuable fruit predictively according to this relationship.

I n California, the most commercially valuable fresh market navel orange fruit are those with average diameters of 72 to $88 \mathrm{~mm}(2.83$ to 3.46 inches). Eighty-eight, 72,56 , or 48 orange fruit with respective aver-

University of California Cooperative Extension, Kern County, 1031 S. Mt. Vernon Ave., Bakersfield, CA 93307.

My thanks to L. Ferguson and J. Karlik for reviewing and improving the manuscript and to the Citrus Research Board in California for its financial assistance. 
age minimum diameters of $72,77,84$, or $88 \mathrm{~mm}(2.83,3.03,3.31$, or 3.46 inches) fill a $17.01-\mathrm{kg}(37.5 \mathrm{lb}) \mathrm{com}-$ mercial carton. In the citrus-producing areas of the southern San Joaquin Valley ofCalifornia, some growers are topping and severely pruning tree interiors with the objective of increasing the number of fruit in this size range. Despite the common practice of more intensive manual pruning and tree topping, pruning guidelines for increasing the number of navel orange fruit sized 88 to 48 per carton are lacking. New efforts toward development of a mechanical picker for oranges destined for the table market has renewed interest in tree pruning methodologies and relationships between fruit numbers and size per tree and per unit land area. Mechanical pickers may require substantial changes in tree architecture involving additional manual or mechanical pruning that could negatively impact yield. While the effects of pruning on yield and other parameters have been more widely investigated in other citrus species such as lemon (C. limon) (Francis et al., 1975) and other sweet orange (C. sinensis) varieties, experiments with navel orange have been comparatively limited and were often conducted before many advances in citriculture, such as clonal protection programs, modern fertilizer practices, and microirrigation were known or instituted (Shamel, 1925; Shamel and Pomeroy, 1942; Surr, 1919). Extrapolating the results of pruning experiments conducted on other species of citrus to navel orange could be misleading. A major determinant of navel orange yield in the San Joaquin Valley and other interior desert valleys, unlike some other citrus varieties, is high temperatures during fruit set (Jennings, 1934; Jones and Cree, 1965). Determining the response of navel orange to pruning can be confounded by yield reductions resulting from high temperatures in May and June. Alternate bearing, an important variable in year-to-year yield in many mandarin (C. reticulata), lemon, and sweet orange varieties, is less significant in navel orange (Jones and Cree, 1965).

Whereas the effect of topping has been reported in the scientific literature for many citrus species (Borrel and Diaz, 1981; Burns et al., 1975; Davies and Albrigo, 1994; Fallahi and Kilby, 1997; Francis et al., 1975; Lee, 1962; Lewis and McCarty, 1973; Morales et al., 1997; Phillips, 1980; Wheaton et al., 1999; Zaragoza and Alfonso, 1981) the response of navel orange to topping appears to have little documentation in the scientific literature. Lewis and McCarty (1973) presented some average values for topped and untopped navel orange orchards that suggest topping had no effect or decreased yields slightly.

The reports of the effects of manual tree pruning on fruit size and fruit numbers per tree in experiments with 'Washington' navel conducted since the 1940s have been mixed. Shamel and Pomeroy (1942), studying 'Washington' navel, found moderate to heavy pruning early in the season decreased the volume of fruit produced per hectare with either no change or a slight increase in individual fruit size. The effects of pruning did not extend into the second or third year after pruning. Moore (1957) found that by removing one or more large limbs from the top and center of 50-year-old navel orange trees, larger fruit of a higher grade were produced with no loss of yield in 2 of the 3 years of the experiment. Evidence from Spain (Zaragoza and Alfonso, 1981), discussed by Davies and Albrigo (1994), suggests total fruit weight and individual fruit size were the same for 'Salustiana' sweet orange trees whether they were pruned annually or every 2,3 , or 6 years. Moreshet et al. (1988) reported that severe pyramidal canopy pruning of 30-year-old 'Shamouti' orange trees reduced fruit weight significantly the following year.

For navel orange and most citrus species, how pruning quantitatively affects the relationship between fruit load and fruit size is not well understood. Knowledge of the relationship between total fruit numbers and the number of the most commercially valuable fruit, if such a general relationship exists, would aid the grower in making pruning decisions for producing fresh market fruit. The objective of this study was to compare the production of the most economically valuable navel orange fruit sizes in response to three levels of manual pruning and three topping heights.

\section{Materials and methods}

The experiment was conducted from Mar. 2000 to Jan. 2004 in a commercial navel orange ['Frost nucellar' on 'Troyer' rootstock (C. sinensis $\mathrm{X}$
Poncirustrifoliata)] orchard planted in 1965 located in the San Joaquin Valley of California. Tree density was 222.4 trees/ha (90 trees/acre) spaced $6.7 \mathrm{~m}$ $(22 \mathrm{ft})$ between and within rows. The soil was a clay loam (fine-loamy, mixed, thermic Calcixerollic Xerochrept). The orchard was originally double planted and thinned to its present density more than 20 years ago.

The experimental design was a blocked split plot with four replications. The main plots were randomly assigned to three topping treatments that would return the trees to the following heights via spring topping: 4.3 $\mathrm{m}, 4.9 \mathrm{~m}$, and untopped, designated as T1, T2, and T3, respectively. Each of these main plots consisted of an area of the orchard nine trees long by four trees wide ( 36 trees in each main plot). This main plot was further divided into three subplots three trees long by four wide ( 12 trees in each subplot). Three manual pruning treatments (severe, designated as Pl), moderate (P2), and none (P3) were randomly assigned to these subplots within each main plot. The 12 trees within each subplot were pruned similarly according to the assigned manual-pruning treatment. Data were collected only from the two trees in the middle of the subplot, which provided a border of similarly pruned trees around the data trees.

The experimental area was topped according to the assigned treatment on 20 Mar. 2000. Trees were "flat topped," not "gable topped." The untopped trees in 2000 ranged in height from 5.2 to $6.1 \mathrm{~m}$ (17 to $20 \mathrm{ft}$ ). Trees were hedged in 2000 only.

The trees were manually pruned according to the assigned treatments between 23 to 27 Mar. 2000. The trees in this orchard, previously, had received little manual pruning and had five to eight large and often intertwined scaffold branches. The severe manual pruning treatment $(\mathrm{Pl})$ consisted of removing two or three of these large scaffold branches, all dead wood, and all green branches up to $25.4 \mathrm{~mm}$ (1 inch) in diameter that could be reached with a pruning shear to a height of 2.4 $\mathrm{m}(8 \mathrm{ft})$ and which were located within $1.2 \mathrm{~m}(4 \mathrm{ft})$ of the central trunk or its hypothetical extension through the center of the tree.

The moderate manual pruning treatment (P2) consisted of removing all live branches up to $25.4 \mathrm{~mm}$ 
diameter that could be reached with a pruning shear to a height of $2.4 \mathrm{~m}$ and that were located within $1.2 \mathrm{~m}$ of the central trunk or its hypothetical extension through the center of the tree. No large scaffold branches were removed and the area of the outer canopy remained largely intact. Any dead wood, regardless of diameter, within reach was also pruned from the tree in both the severe and moderate manual pruning treatments. The third treatment $(\mathrm{P} 3)$ consisted of no manual pruning.

In Mar. 2000, leaf and wood prunings were collected and weighed in bulk from each main plot after topping, and from the two data trees within each subplot after manual pruning. The average fresh weight of pruned material removed per tree in each operation was calculated by dividing the total plant material collected by the number of trees pruned. New trunk and scaffold sprouts were removed in June 2000 in severely and moderately pruned treatments.

Trees were topped at the same treatment heights in the same experimental plots in Mar. 2000, Mar. 2001, and Mar. 2002. In 2003 the trees were not topped. The trees in the subplots that were severely manually pruned (Pl) and those that were moderately manually pruned in 2000 (P2) were lightly manually pruned in Mar. 2001, which consisted of removal of about $50 \%$ of the new sprouts in the lower $2.4 \mathrm{~m}$ of tree canopy. Both Pl and P2 trees were moderately manually pruned in Feb. 2002 as described for P2 trees in Mar. 2000, except that some sprouts were left on the scaffolds below $2.4 \mathrm{~m}$ to encourage interior fruit production. No manual pruning was conducted in 2003 .

In the second and third years of the experiment, the distribution of wood that was pruned from the tree either by topping or manually appeared to be similar between the treatments. Prunings were collected and weighed in bulk across pruning treatments after topping and after manual pruning. No manual pruning was conducted in treatment $\mathrm{P} 3$ in any year.

The trees were harvested 7 Dec. 2000 (year 1), 7 Jan. 2002 (year 2), 11 Dec. 2002 (year 3), and 12 Jan. 2004 (year 4). Fruit weight, fruit numbers, fruit size, grade, and color were measured at the University of California Lindcove Research and Extension
Center experimental packline the day after harvest.

Data were analyzed using ANOVA/MANOVA and General Linear Model statistical packages in Statistica software (StatSoft, Inc., Tulsa, Okla.). Standard $F$-tests in all analyses were used to determine significance of whole plot, subplot, and interaction effects. Means separation using Fishers least significance difference test was employed only when $F$-tests indicated significance at $P \leq 0.05$.

\section{Results and discussion}

The average weight of fresh wood and leaves removed from trees in the three topping and three manual pruning treatments in Mar. 2000 are listed in Table 1. At topping in Mar. 2000, the untopped trees (T3) were similar in height to moderately topped trees (T2) so wood and foliage removal was minimal (Table 1). Subsequent annual topping maintained tree height of T2 at $4.9 \mathrm{~m}$ while the untopped trees continued to increase in height through the experiment. Foliage and wood removal by topping was light compared to severe manual pruning (Table 1).

Fresh weight of wood removed by annual topping $\mathrm{Tl}$ and $\mathrm{T} 2$ averaged 5.8 $\mathrm{kg}(12.79 \mathrm{lb})$ per tree in 2001 and 3.6 $\mathrm{kg}(7.94 \mathrm{lb})$ per tree in 2002. Fresh weight of wood removed by manual pruning in $\mathrm{Pl}$ and $\mathrm{P} 2$ averaged $8.1 \mathrm{~kg}$ $(17.86 \mathrm{lb})$ per tree in $200 \mathrm{l}$ and 18.6 $\mathrm{kg}(41.01 \mathrm{lb})$ per tree in 2002 .

Cumulative topping efFects. Data from Pl (severely pruned) trees were eliminated from the statistical analysis comparing the effects of topping height on the various parameters investigated. Only moderately pruned (P2) and unpruned (P3) trees were compared among the three topping treatments as the severity of the pruning in $\mathrm{Pl}$ trees overwhelmed topping effects. No significant differences were found with respect to yield, fruit numbers per tree, fruit size, or other quality factors among topping heights in any of the 4 years of the experiment (Table 2) nor was there any relationship between the fresh weight of wood removed per tree by topping and fruit yield (data not shown). The results demonstrate that a topping height of $4.3 \mathrm{~m}$ for trees spaced $6.7 \mathrm{~m}$ between rows and individual trees within a row produced similar yields to trees topped at $4.9 \mathrm{~m}$ and to untopped trees that by 2003 had reached heights of $5.5 \mathrm{~m}$ $(18 \mathrm{ft})$ to $6.4 \mathrm{~m}(2 \mathrm{lft})$.

Cumulative manual pruning EFFECTS. Cumulatively, over the 4 years of the experiment, treatment $\mathrm{Pl}$ produced lesser yields of fruit by weight and numbers than P2 or P3

Table 1. Fresh weight of leaves and wood removed by initial topping and manual pruning of mature 'Frost nucellar' navel orange trees in Mar. 2000.

\begin{tabular}{|c|c|c|c|c|c|c|c|}
\hline \multicolumn{2}{|c|}{ Topping } & \multirow{2}{*}{$\begin{array}{l}\text { Fresh wt } \\
(\mathrm{kg})^{\mathrm{z}}\end{array}$} & \multirow{2}{*}{$\begin{array}{l}\mathrm{SD} \\
(\mathrm{kg})\end{array}$} & \multicolumn{2}{|c|}{ Manual pruning } & \multirow{2}{*}{$\begin{array}{c}\text { Fresh wt } \\
(\mathrm{kg})\end{array}$} & \multirow{2}{*}{$\begin{array}{c}\mathrm{SD} \\
(\mathrm{kg})\end{array}$} \\
\hline$\overline{\mathrm{Ht}}$ & Code & & & Treatment & Code & & \\
\hline $4.3 \mathrm{~m}(14 \mathrm{ft})$ & $\mathrm{Tl}$ & 24.2 & 3.0 & Severe & $(\mathrm{Pl})$ & 149.7 & $41.1^{y}$ \\
\hline $4.9 \mathrm{~m}(16 \mathrm{ft})$ & $\mathrm{T} 2$ & 1.9 & $1.1^{x}$ & Moderate & $(\mathrm{P} 2)$ & 31.7 & $13.2^{y}$ \\
\hline None & $\mathrm{T} 3$ & 0 & & None & (P3) & 0 & \\
\hline
\end{tabular}

${ }^{\mathrm{z}} 1.0 \mathrm{~kg}=2.205 \mathrm{lb}$.

${ }^{\mathrm{y}} \mathrm{n}=12$, each subplot replicate $(\mathrm{n})$ is the average of two trees.

${ }^{x} n=4$, each whole plot replicate $(n)$ is the average of 36 trees.

Table 2. The effect of mechanical topping on per tree cumulative fruit weight, fruit numbers and commercially valuable fruit sizes of mature 'Frost nucellar' navel orange in $2000-03$.

\begin{tabular}{|c|c|c|c|c|}
\hline \multicolumn{2}{|c|}{ Topping } & \multirow{2}{*}{$\begin{array}{c}\text { Cumulative } \\
\text { yield } \\
(\mathrm{kg} / \text { tree })^{\mathrm{y}}\end{array}$} & \multirow{2}{*}{$\begin{array}{l}\text { Fruit sized } \\
\text { Total fruit } \\
\text { (no./tree) }\end{array}$} & \multirow{2}{*}{$\begin{array}{c}72-88 \mathrm{~mm}^{\mathrm{z}} \\
\text { (no./tree) }\end{array}$} \\
\hline $\mathrm{Ht}$ & Code & & & \\
\hline $4.3 \mathrm{~m}(14 \mathrm{ft})$ & $(\mathrm{T} 1)$ & $794 a^{x}$ & $3304 \mathrm{a}$ & $2092 \mathrm{a}$ \\
\hline $4.9 \mathrm{~m}(16 \mathrm{ft})$ & (T2) & 898 a & $3737 \mathrm{a}$ & $2385 \mathrm{a}$ \\
\hline No top & (T3) & $837 \mathrm{a}$ & $3491 \mathrm{a}$ & $2143 a$ \\
\hline
\end{tabular}

${ }^{\mathrm{z}}$ Average fruit diameters of $72 \mathrm{~mm}$ (2.83 inches) and $88 \mathrm{~mm}$ (3.46 inches) correspond to 88 and 48 fruit, respectively, per $17.01 \mathrm{~kg}(37.5 \mathrm{lb})$ California commercial carton.

${ }^{y} 1 \mathrm{~kg}=2.205 \mathrm{lb}$.

${ }^{\mathrm{x}}$ Means separation within columns by Fisher's protected least significant difference test, $P \leq 0.05$. Values within a column with the same letter are not significantly different. No significant "pruning $x$ topping" or "pruning $\times$ block" interactions were found for any variable in any year. Data from Pl subplots were not included in this analysis do to its severity to avoid confounding the topping results. 
(Table 3). A greater percentage of the total fruit on the tree were larger in treatment Pl but, more importantly from an economic standpoint, the numbers of economically valuable fruit were greater in P2 and P3 (Table 3). Another factor important in deciding to prune an orchard is cost. After 4 years, manual pruning costs alone in treatment $\mathrm{Pl}$, not including the increased cost of shredding the prunings, amounted to $\$ 13$ per tree or \$2891/ha (\$1170/acre) (Table 4). Most of this cost was incurred the first year when large scaffold branches were removed.

MANUAL PRUNING EFFECTS IN 2000 (YEAR 1). The severe manual pruning treatment $(\mathrm{Pl})$ done in Mar. 2000 greatly reduced yield based on weight of fruit and the number of fruit harvested (Table 5). A highly significant regression existed between yield, by weight of fruit per tree, and the average weight of fresh wood removed per tree in Mar. 2000 [yield of fruit in kilograms $=358.4-1.704 \times$ (fresh weight of wood in kilograms); adjusted $\left.\mathrm{r}^{2}=0.97\right]$. A decrease in yield with heavy manual pruning was previously documented by Shamel and
Pomeroy (1942) and Surr (1919) for navel orange and for most other citrus species (Davies and Albrigo, 1994; Lewis and McCarty, 1973; Moreshet et al., 1988). Position of the pruned wood in the canopy (Fig. 1) may explain why removing wood through manual pruning resulted in greater yield loss than by topping in this experiment. The lack of topping effect, even when $1 \mathrm{~m}$ $(3.3 \mathrm{ft})$ of canopy was removed, is probably attributable to the observation that the unshaded fruit bearing area of the outer tree canopy between topped and untopped trees remained relatively constant. Observations suggested that topping moved the fruit-bearing area of the canopy closer to the ground probably in response to greater light penetration into the lower portion of the canopy.

While topping did little to change the fruit-bearing area of the canopy, manual pruning of two or three of the intertwined scaffold branches in 2000 resulted in an overall decrease in canopy integrity and diameter when branches associated with these scaffolds were removed. In response to the canopy reduction and less fruit produced, the remaining fruit on the
Table 3. The effect of manual pruning mature 'Frost nucellar' navel orange on per tree cumulative fruit weight, fruit number, percentage of fruit greater than $72-\mathrm{mm}$ diameter $(2.83$ inches $)$ and number of fruit sized 72 to $88 \mathrm{~mm}$ (3.46 inches) diameter from 2000 to 2003.

\begin{tabular}{|c|c|c|c|c|}
\hline \multirow[b]{2}{*}{$\begin{array}{l}\text { Manual } \\
\text { pruning }^{\mathrm{y}}\end{array}$} & \multirow{2}{*}{$\begin{array}{c}\text { Cumulative } \\
\text { yield } \\
\left(\mathrm{kg} / \text { tree }^{\mathrm{x}}\right.\end{array}$} & \multirow[b]{2}{*}{$\begin{array}{c}\text { Fruit } \\
\text { (no./tree) }\end{array}$} & \multicolumn{2}{|c|}{ Fruit diam } \\
\hline & & & $\begin{array}{c}>72 \mathrm{~mm}^{\mathrm{z}} \\
(\%)\end{array}$ & $\begin{array}{c}72-88 \mathrm{~mm}^{\mathrm{z}} \\
\text { (no./tree) }\end{array}$ \\
\hline $\mathrm{Pl}$ & $681 b^{w}$ & $2456 \mathrm{c}$ & $83 \mathrm{a}$ & $1941 \mathrm{~b}$ \\
\hline $\mathrm{P} 2$ & $811 \mathrm{a}$ & $3340 \mathrm{~b}$ & $73 \mathrm{~b}$ & $2652 \mathrm{a}$ \\
\hline P3 & $876 a$ & 3681 a & $70 \mathrm{~b}$ & $2864 \mathrm{a}$ \\
\hline
\end{tabular}

${ }^{2}$ Average fruit diameters of 72 and $88 \mathrm{~mm}$ correspond to 88 and 48 fruit, respectively, per $17.01-\mathrm{kg}$ (37.5 lb) California commercial carton.

'Manual pruning treatments: $\mathrm{Pl}=$ trees severely pruned in 2000 , lightly pruned in 2001 and moderately pruned in $2002 ; \mathrm{P} 2=$ trees moderately pruned in 2000 and 2002 and lightly pruned in 2001; $\mathrm{P} 3=$ trees received no manual pruning.

${ }^{x} 1 \mathrm{~kg}=2.205 \mathrm{lb}$.

wMeans separation within columns by Fisher's protected least significant difference test, $P \leq 0.05$. Values within a column with the same letter are not significantly different. tree became overly large, coarse, and misshapen reducing the percentage of U.S. fancy (top grade) fruit (Table $5)$. This decline in fancy fruit in 2000 was the only difference found among treatments for any fruit characteristic other than fruit size during the 4 years of this experiment. Fruit from the trees that were not manually pruned (treatment P3), or those that were moderately pruned in 2000 (treatment P2) peaked at harvest on fruit sized $77 \mathrm{~mm}$ diameter ( 72 fruit per standard California 17.01-kg carton), while those in the severely pruned plot (treatment P3), peaked on sizes larger than $88 \mathrm{~mm}$ diameter (less than 48 fruit per carton) (Table 5).

A significant relationship existed between the total fruit produced per ha and the number of valuable fruit (those sized 72 to $88 \mathrm{~mm}$ diameter) (Fig. 1). The adverse effect that the severe pruning treatment had on yield is apparent in Fig. 1.

MANUAL PRUNING EFFECTS IN 2001, 2002, AND 2003. In year 2 of the experiment (2001), trees in treatment $\mathrm{Pl}$ produced similarly to trees in P2 and P3 (Table 6). Yield of fruit was low in 2001 (Fig. 2, Table 6) probably as a result of an excessive natural fruit drop occurring in response to unusually high May temperatures (Jennings, 1934; Jones and Cree, 1965). At harvest in year 3 (2002), a year with higher potential fruit set, trees in treatment $\mathrm{P} 3$ produced more

Table 4. The average cumulative costs of manual pruning mature 'Frost nucellar' navel orange trees in dollars and in labor in 2000-02.

\begin{tabular}{llcc}
\hline \multirow{2}{*}{$\begin{array}{l}\text { Manual pruning } \\
\text { treatment }\end{array}$} & \multicolumn{2}{c}{ Cost $^{\mathrm{z}}$} \\
\cline { 3 - 4 } & $(\mathbf{\$} /$ tree $)$ & labor $(\mathrm{h} /$ tree $)$ \\
\hline Severe & (P1) & 13.00 & 1.24 \\
Moderate & (P2) & 8.25 & 0.8 \\
None & (P3) & 0.0 & 0.0 \\
\hline
\end{tabular}

${ }^{2}$ Does not include topping, hedging, or brush shredding costs.

Table 5. The effects of manual pruning on yield and fruit quality parameters of mature 'Frost nucellar' navel orange for the harvest following initial spring pruning in 2000.

\begin{tabular}{|c|c|c|c|c|c|c|c|c|c|c|c|}
\hline \multirow{2}{*}{$\begin{array}{l}\text { Manual } \\
\text { pruning }\end{array}$} & \multirow{2}{*}{$\begin{array}{c}\text { Treatment } \\
\text { code }\end{array}$} & \multirow{2}{*}{$\begin{array}{c}\text { Yield } \\
(\mathrm{kg} / \text { tree })^{x}\end{array}$} & \multirow{2}{*}{$\begin{array}{c}\text { Fruit } \\
\text { (no./tree) }\end{array}$} & \multirow{2}{*}{$\begin{array}{c}\text { U.S. Fancy } \\
(\%)\end{array}$} & \multicolumn{7}{|c|}{ No. of fruit in designated size classes $(\mathrm{mm})^{y}$} \\
\hline & & & & & $<66$ & 66 & 72 & 77 & 84 & 88 & $>88$ \\
\hline Severe & $\mathrm{Pl}$ & $122 b^{w}$ & $352 \mathrm{c}$ & $34 \mathrm{~b}$ & $6 \mathrm{~b}$ & $12 \mathrm{c}$ & $17 \mathrm{c}$ & $40 \mathrm{c}$ & $75 \mathrm{~b}$ & $66 a$ & $136 \mathrm{a}$ \\
\hline None & P3 & $208 \mathrm{a}$ & $982 \mathrm{a}$ & 53 a & $33 \mathrm{a}$ & $164 \mathrm{a}$ & $205 \mathrm{a}$ & $270 \mathrm{a}$ & $188 \mathrm{a}$ & $73 \mathrm{a}$ & $49 \mathrm{~b}$ \\
\hline
\end{tabular}

${ }^{2}$ U.S. fancy designates the highest fruit grade and is based primarily on cosmetic appearance and rind smoothness.

yverage fruit diameters of $66,72,77,84,88$, and $>88 \mathrm{~mm}(2.60,2.83,3.03,3.31,3.46$, and $>3.46$ inches $)$ correspond to $113,88,72,56,48$, and $<48$ fruit, respectively, per $17.01-\mathrm{kg}(37.5 \mathrm{lb})$ California commercial carton.

${ }^{\mathrm{x}} 1 \mathrm{~kg}=2.205 \mathrm{lb}$.

"Means separation within columns by Fisher's protected least significant difference test, $P \leq 0.05$. Values within a column with the same letter are not significantly different. 


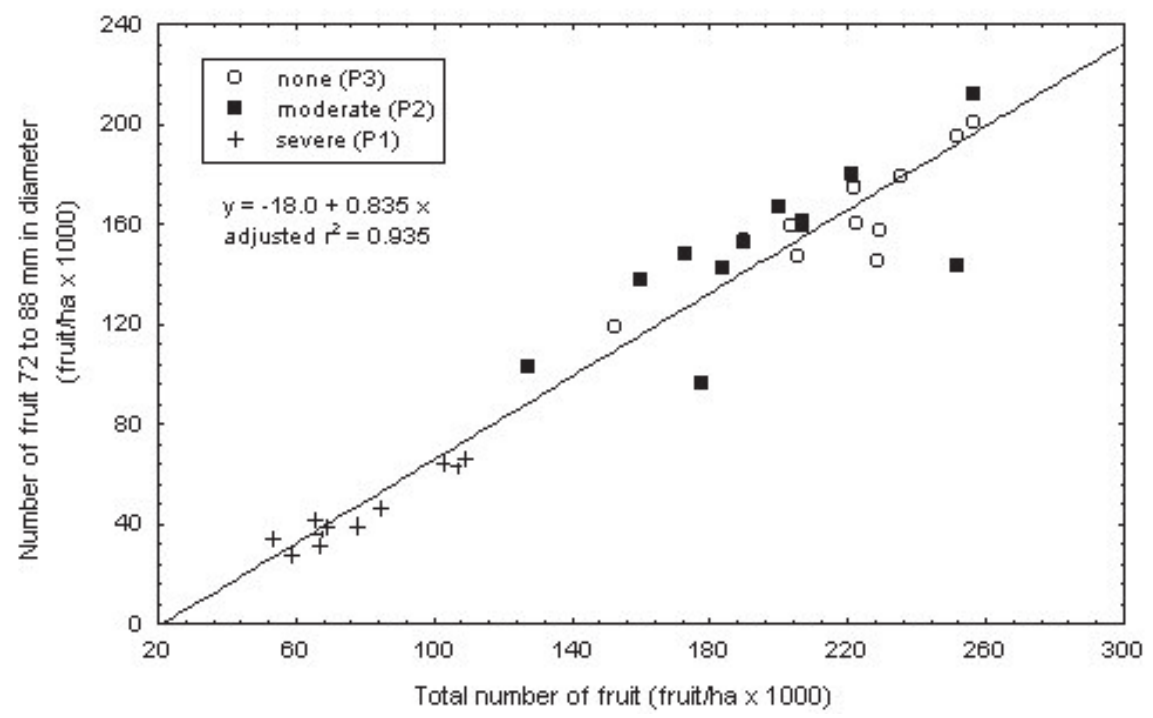

Fig. 1. The relationship between the total number of fruit produced per hectare in the first year of the experiment (2000) vs. the numbers of commercially valuable fruit produced per hectare in response to manual pruning severity is displayed for 'Frost nucellar' navel orange. Each point on the graph represents the results from one manual pruning subplot; 1000 fruit $/$ ha $=404.7$ fruit $/$ acre; $25.4 \mathrm{~mm}=1$ inch.

fruit per tree than those in treatment $\mathrm{Pl}$, but the number of commercially valuable fruit was not different from Pl trees (Table 6). Trees in treatment P2 performed similarly to P3 trees. In year 4 (2003), fruit yield, both by weight and numbers in treatments P2 and P3, was the largest of the 4 years (Fig. 2, Table 6) with the highest yields exceeding $60 \mathrm{t} \cdot \mathrm{ha}^{-1}$ (26.8 tons/acre). For the same year (2003) average county yield was $29.411 \mathrm{t} \cdot \mathrm{ha}^{-1}(13.12$ tons/acre), which was low compared to the experimental orchard, but which was greater than average county yields in most other years since 1960 (Davis, 2003). Treatment Pl in year 4 produced less total yield and fewer commercially valuable fruit than P2 or P3 (Table 6), although the differences among treatments were not as large as in 2000 (Table 5 ). The canopies of Pl trees remained smaller than in $\mathrm{P} 2$ and P3 trees despite the absence of any topping or manual pruning having occurred the previous year. In years of high yield potential, such as in year 4 , the reduced canopy of the P3 trees apparently resulted in lower yields compared to unpruned or moderately pruned trees. These data suggest that the potential yield of the orchard in a given year can be a significant factor in evaluating the effects of a given pruning treatment. In a year with a high fruit production potential, pruned trees may be more likely to perform differently than unpruned trees. There were no significant differences in fruit grade among treatments in year 2, 3, or 4 .

RELATIONSHIP BETWEEN TOTAL ANNUAL FRUIT PRODUCTION AND COMMERCIALLY VALUABLE FRUIT 2000-03. As discussed above, yield, as measured both in fruit numbers and weight of fruit, in this study, and in other studies with citrus (Lewis and McCarty, 1973; Wheaton et al, 1999), decreased with the severity of manual pruning, and that this decrease in yield was corre- lated with the amount of tree canopy removed. For the 'Frost nucellar' navels in this experiment, every year the number of commercially valuable fruit (sized 72 to $88 \mathrm{~mm}$ diameter) was positively and linearly correlated to the total number of fruit annually produced in this orchard (Fig. 2). Whether lower fruit set resulted from environmental conditions (as in 2001 across all treatments), or from severe hand pruning (in 2000), the relationship between total fruit number and economically valuable fruit remained unchanged (Fig. 2). Within this study, anything reducing fruit numbers below approximately 325,000 fruit/ha, the maximum yields recorded, reduced the number of valuable fruit. The relationships between the numbers of fruit of a given size and the total number of fruit produced annually per ha (fruit 72 and $84 \mathrm{~mm}$ diameter shown individually in Fig. 3) were similar to the relationship between the sum of the valuable fruit sizes and the total annual number of fruit produced. Fruit numbers in a given size category increased with total fruit production. In examining the data points in Fig. 3, few fruit with an average diameter of $72 \mathrm{~mm}$ are harvested until total fruit numbers exceed 150,000 fruit/ha (60,705 fruit/acre).

Grower observations that fruit on the tree generally appear larger in the season after a severe pruning treatment or in a season when few fruit are produced per tree are supported by results displayed in Fig. 4 and Table 5. A greater percentage of fruit on severely pruned trees were large (i.e., greater than $72 \mathrm{~mm}$ diameter) but because total fruit numbers were much reduced compared to unpruned trees, the total number of commercially valuable fruit per tree or per ha were reduced as well (Figs. 2, 3, and 4). With fewer fruit per tree produced after the severe pruning in 2000, many of the fruit grew overly large (i.e., greater than $88 \mathrm{~mm}$ diam-

Table 6. The affect of manual pruning on annual yield and fruit diameter of mature 'Frost nucellar' navel orange for Years 2,3 , and $4(2001,2002$, and 2003$)$ of the experiment.

\begin{tabular}{|c|c|c|c|c|c|c|c|c|c|c|}
\hline \multicolumn{2}{|c|}{ Manual pruning } & \multicolumn{3}{|c|}{ Yield $(\mathrm{kg} / \text { tree })^{\mathrm{z}}$} & \multicolumn{3}{|c|}{ Total fruit (no./tree) } & \multicolumn{3}{|c|}{ Fruit $72-88 \mathrm{~mm}^{\mathrm{y}}$ (no./tree) } \\
\hline Treatment & Code & 2001 & 2002 & 2003 & 2001 & 2002 & 2003 & 2001 & 2002 & 2003 \\
\hline Severe & $\mathrm{Pl}$ & $151 a^{x}$ & $179 \mathrm{a}$ & $229 \mathrm{~b}$ & $447 \mathrm{a}$ & $749 \mathrm{~b}$ & $909 \mathrm{~b}$ & $287 \mathrm{a}$ & $659 a$ & $798 \mathrm{~b}$ \\
\hline None & P3 & $184 \mathrm{a}$ & $197 \mathrm{a}$ & $286 a$ & $542 \mathrm{a}$ & 905 a & $1252 \mathrm{a}$ & $324 \mathrm{a}$ & $751 \mathrm{a}$ & $1053 \mathrm{a}$ \\
\hline
\end{tabular}

${ }^{\mathrm{z}} 1 \mathrm{~kg}=2.205 \mathrm{lb}$.

yAverage fruit diameters of 72 and $88 \mathrm{~mm}(2.83$ and 3.46 inches) correspond to 88 and 48 fruit, respectively, per $17.01-\mathrm{kg}$ (37.5 lb) California commercial carton.

${ }^{x}$ Means separation within columns by Fisher's protected least significant difference test, $P \leq 0.05$. Values within a column with the same letter are not significantly different.

No significant "pruning topping" or "pruning $\times$ block" interactions were found for any variable in any year. 


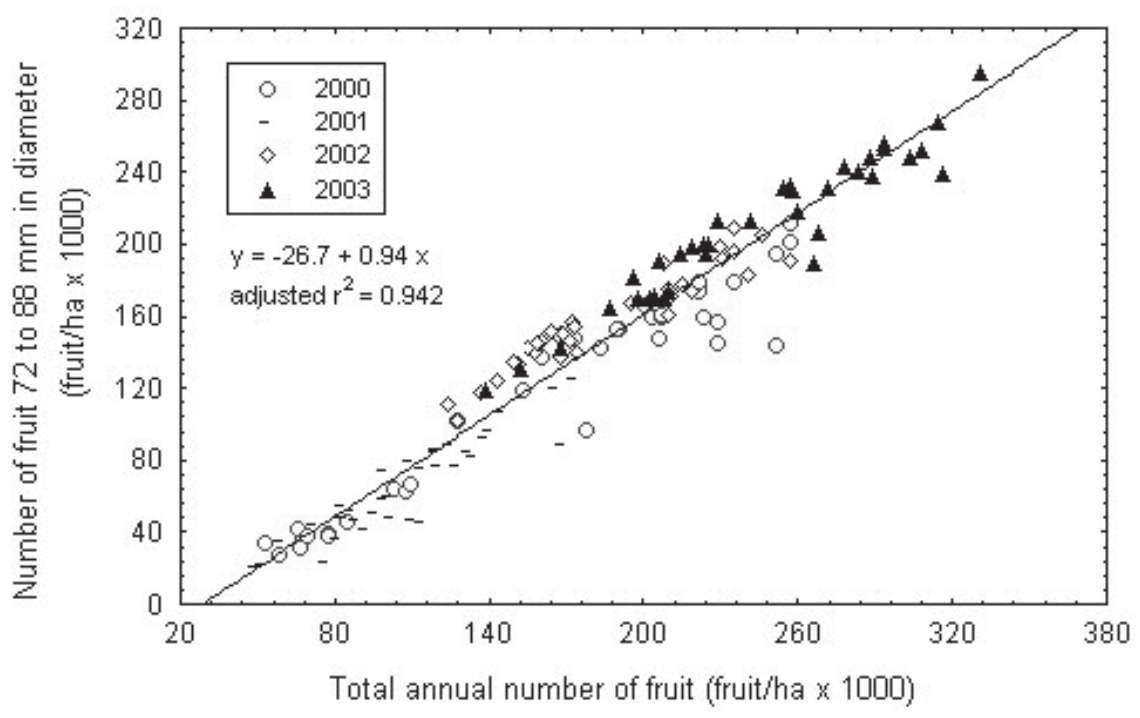

Fig. 2. The relationship between the numbers of fruit produced annually per hectare vs. the numbers of the most commercially valuable fruit produced annually per hectare is displayed for mature 'Frost nucellar' navel orange. Average fruit production in the San Joaquin Valley of California is approximately 160,000 to $200,000 \mathrm{fruit} / \mathrm{ha}$. Each point on the graph represents results from 1 manual pruning subplot for the given year; 1000 fruit $/$ ha $=404.7$ fruit $/$ acre; $25.4 \mathrm{~mm}=1$ inch.

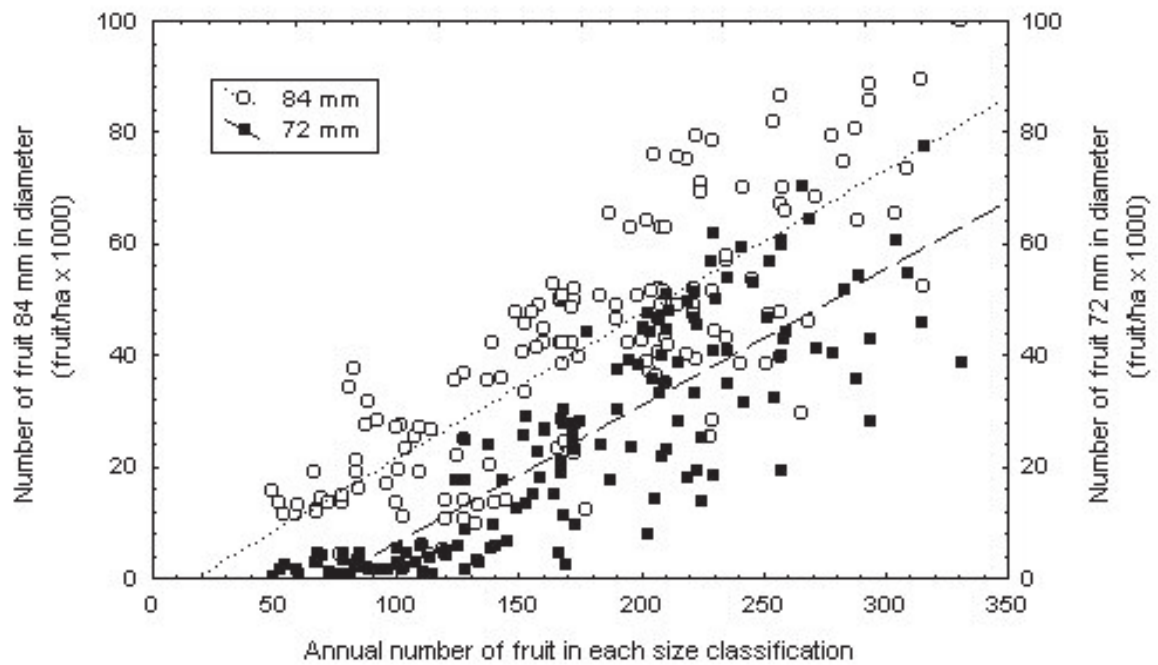

(fruitha $\times 1000$ )

Fig. 3. The relationship between the total numbers of fruit produced annually per hectare vs. the numbers of fruit $72 \mathrm{~mm}$ average diameter [ 88 fruit per 17.01 $\mathrm{kg}(37.5 \mathrm{lb})$ carton] or $84 \mathrm{~mm}$ average diameter (48 fruit/carton) produced per hectare is displayed for mature 'Frost nucellar' navel orange. Only two size classifications shown for clarity, although other class sizes performed similarly. Each point on the graph represents results from 1 manual pruning subplot. 1000 fruit $/$ ha $=404.7$ fruit $/$ acre; $25.4 \mathrm{~mm}=1$ inch .

eter) and thus less marketable before reaching legal sweetness and color maturity (Table 5 ). The results displayed in Fig. 4 are compatible with the results of Parker (1934), who showed an inverse linear relationship between the mean number of packed boxes of fruit shipped per acre and the mean num- ber of fruits per packed box for both Valencia and navel orange. Likewise Goldschmidt and Monselise (1977) demonstrated an inverse relationship between number of fruits per tree and individual fruit weight or size. In my experiment, when relatively small numbers of fruit were produced per hectare, as occurred as a result of severe pruning or weather-related cause, the majority of the fruit that were not of commercial size were overly large (i.e., greater than $88 \mathrm{~mm}$ diameter). When fruit numbers were relatively greater, the majority of this less valuable fruit were too small (i.e., less than $72 \mathrm{~mm}$ diameter). In Fig. 2, approximately 33,000 fruit/ha (13,355 fruit/acre) are shown to be outside of the valuable fruit classification when total fruit yield is approximately 100,000 fruit/ha $(40,470$ fruit/acre $)$ vs. about 45,000 fruit/ha (18,212 fruit/acre) when total fruit yield is approximately 300,000 fruit/ha $(121,410$ fruit/ acre). Picking efficiency may change depending on fruit size (Whitney et al. 1995), but picking costs associated with picking a relative difference of 12,000 less valuable fruit per hectare (4856 fruit/acre) would not offset the profit associated with producing higher yields of economically valuable fruit (O'Connell et al., 2002). In addition, many orange production costs other than picking, such as pest control and irrigation, remain the same whether yields are high or low, so net returns to growers are usually greater when the numbers of valuable fruit harvested are maximized (O'Connell et al., 2002).

Over the 4 years of this study, a highly significant and positive regression $\left(r^{2}=0.82\right)$ existed between yield by weight and numbers of fruit sized 72 to $88 \mathrm{~mm}$ diameter (regression not shown) suggesting that obtaining greater numbers of commercially valuable fruit per ha without a concomitant increase in yield by weight per ha is unlikely.

The results from this experiment suggest navel orange trees should not be manually pruned if the reason for this pruning is to increase the number of the most commercially valuable fruit sizes. Any future changes in tree density or pruning style necessary to accommodate mechanical pruning in this orchard or in a new navel orange orchard with an early or midseason harvest, should allow for a potential production capacity of at least 300,000 fruit/ha (121,410 fruit/acre) to maximize the number of the most commercially valuable fruit sizes [approximately 255,000 fruit/ha (103,199 fruit/acre) $]$ in years with high yield potentials.

Trees, at a density of 222.4 trees/ha (90 trees/acre), topped an- 


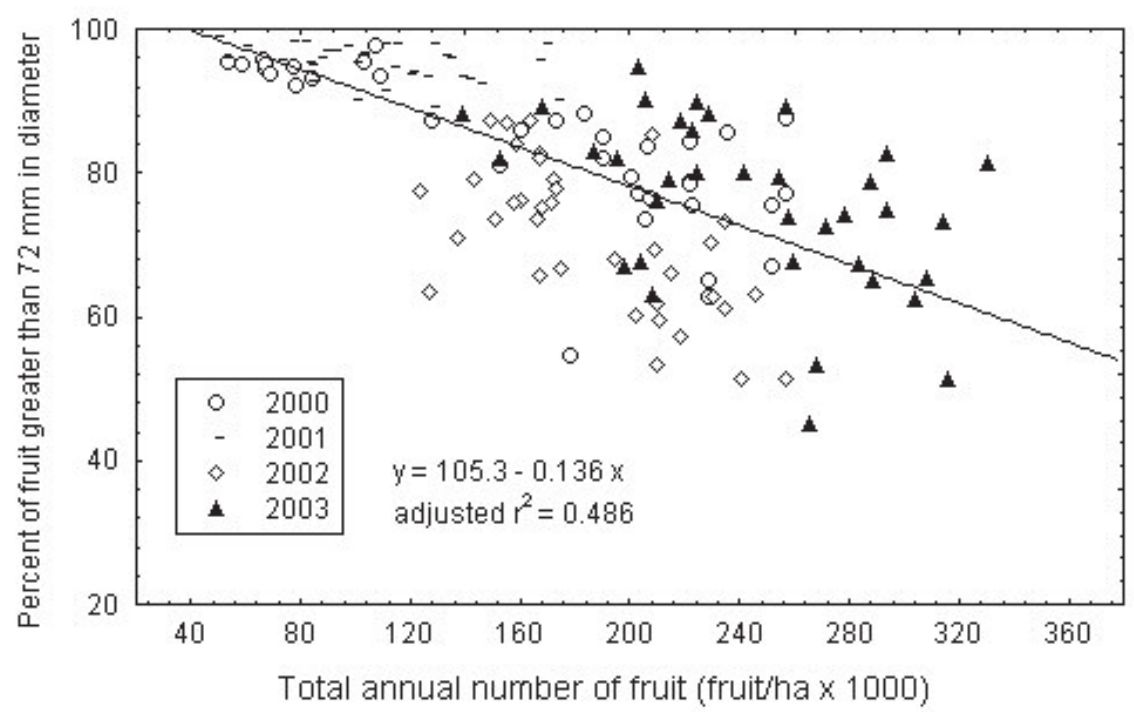

Fig. 4. The relationship between the total numbers of fruit produced annually per hectare and the percentage of fruit greater than $72 \mathrm{~mm}$ diameter is displayed for mature 'Frost nucellar' navel orange. Each point on the graph represents results from one manual pruning subplot for the given year. 1000 fruit $/$ ha $=$ 404.7 fruit/acre; $25.4 \mathrm{~mm}=1$ inch.

nually at the $4.3-\mathrm{m}$ height produced similar yields and sizes of fruit to trees substantially taller which supports the observations of Lewis and McCarty (1973). Reduced tree height is advantageous in that it enhances picking efficiency and worker safety (Whitney et al., 1995).

The results from this experiment are considered to be applicable to most orchards in the San Joaquin Valley of California, which are harvested midseason, from December through February, in which total fruit production does not exceed 325,000 fruit/ha.

\section{Literature cited}

Borrel, M. and A. Diaz. 1981. Effects of mechanical pruning on yield of citrus trees. Proc. Intl. Soc. Citricult. 1:190-194.

Burns, R.M., S.B. Boswell, S.F. Wer, and C.D. McCarty. 1975. Comparison of pruning methods of mature Lisbon lemons. Calif. Citrograph 60:344, 373-374.

Davies, F.S. and L.G. Albrigo. 1994. Pruning, p. 158-161. In: Citrus: Crop production science in horticulture. $\mathrm{CAB}$ Intl., Trowbridge, U.K.

Davis, T.K. 2003. Kern County agricultural crop report. 24 Sept. 2004. <http:// www.co.kern.ca.us/kernag/crop00-09/ crop03/FruitNut4.pdf>.
Fallahi, E. and M. Kilby. 1997. Rootstock and pruning influences yield and fruit quality of 'Lisbon' lemon. Fruit Var. J. 51:242-246.

Francis, H.L., M. Miller, S. Boswell, and C. Colladay. 1975. An economic analysis of three lemon pruning methods. Calif. Citrograph 61:12, 24-26, 43.

Goldschmidt, E.E. and S.P. Monselise. 1977. Physiological assumptions toward the development of a citrus fruiting model. Proc. Intl. Soc. Citricult. 2:668-672.

Jennings, R.F. 1934. Effect of weather in influencing navel yields. Calif. Citrograph 20:34-35.

Jones, W.W. and C.B. Cree. 1965. Environmental factors related to fruiting of Washington navel oranges over a 38year period. Proc. Amer. Sci. Hort. Sci. 86:267-271.

Lee, B.W. 1962. Hedging and topping of mature Valencia orange trees. Calif. Citrograph 48:42,52,53

Lewis, L.N. and C.D. McCarty. 1973. Pruning and girdling citrus, p. 211-215. In: W. Reuther (ed.). The citrus industry. Vol. III. Univ. of Calif., Division of Agr. Sci., Berkeley.
Moore, P.W. 1957. Pruning makes cents. Calif. Citrograph 42:110, 122.

Morales, P., F.S. Davies, and R.C. Littell. 1997. Pruning and skirting affect canopy microclimate, yields and fruit quality of ' $\mathrm{Or}$ lando’ tangelo. HortScience 35:30-35.

Moreshet, S., Y. Cohen, and M. Fuchs. 1988. Water use and yield of a mature Shamouti orange orchard submitted to root volume restriction and intensive canopy pruning. Proc. Sixth Intl. Citrus Congr., Tel Aviv, Israel. p. 739-746.

O'Connell, N., K. Klonsky, M. Freeman, C. Kallsen, and R. De Moura. 2002. Sample costs to establish an orange orchard and produce oranges. San Joaquin Valley-south. OR-VS-02. 17 Sept. 2004. <http://www. agecon.ucdavis.edu/outreach/crop/coststudies/2002OrangeSJV.pdf>.

Parker, E.R. 1934. Some effects of thinning orange fruits. Univ. of Calif., College of Agr., Agr. Expt. Sta. Bul. 576.

Phillips, R.L. 1980. Hedging and topping practices for Florida citrus. Citrus Ind. 61:5-10.

Shamel, A.D. 1925. Performance records of pruned and unpruned Washington navel trees for a period of ten years. Calif. Citrograph 10:415, 442-443, 445.

Shamel, A.D. and C.S. Pomeroy. 1942. Effects of pruning old Washington navel orange trees. Proc. Amer. Soc. Hort. Sci. 41:71-76.

Surr, G. 1919. Yields of Washington navel oranges in relation to pruning. Calif. Citrograph 4:290, 325.

Wheaton, T. A., W.S. Castle, J.D. Whitney, and D.P.H. Tucker. 1999. Horticultural practices for citrus health, p. 49-58. In: L.W. Timmer and L.W. Duncan (eds.). Citrus health management. APS Press, St. Paul, Minn.

Whitney, J.D., T.A. Wheaton, W.S. Castle, and D.P.H. Tucker. 1995. Tree height, fruit size, and fruit yield affect manual orange harvesting rates. Proc. Fla. State Hort. Soc. 108:112-118.

Zaragoza, S. and E. Alfonso. 1981. Citrus pruning in Spain. Proc. Intl. Soc. Citricult. 1:172-175. 